\title{
Genetic relationship of asiatic hard clam populations collected in northern coastal provinces in Vietnam based on mtDNA sequence analysis
}

\begin{abstract}
The genetic relationship of some Asiatic hard clam (Meretrix meretrix) based on mtDNA COI sequence analysis was investigated for populations collected in Thai Binh, Nam Dinh, Nghe An provinces in Vietnam. In addition, this research also targets at species identification based on COI sequences. In total of 59 sequences analyzed, 19 sequences belonged to Meretrix meretrix species with Gen Bank accession number DQ399399.1. 17 sequences of $M$. meretrix were used for genetic relationship analysis among 3 populations. In which, 6 polymorphic sites, 3 parsimony informative sites and 4 haplotypes observed for the COI gene. Moderately genetic population diversity was observed, overall haplotype and nucleotide diversity were $0.476 \pm 0.233$ and $0.00151 \pm 0.00069$, respectively. Generally, genetic differentiation $\left(\mathrm{F}_{\mathrm{ST}}\right)\left(\mathrm{F}_{\mathrm{ST}}<0.15\right)$ was moderate. The genetic distance was rather low, which ranged from 0.001 (Thai Binh-NgheAn, Thai Binh-Nam Dinh populations) to 0.002 (Nam Dinh - Nghe An populations). The result of haplotype network constructing indicated that populations shared common haplotype and there was no specific isolation of the haplotypes of the populations. Hence, it showed M. meretrix populations had intimate genetic relationship. The result of phylogenic tree indicated that three $M$. meretrix populations (Thai Binh, Nam Dinh, Nghe An) had a very small or no genetic variation among populations.
\end{abstract}

Keywords: Population, genetic diversity, genetic relationship, meretrixmertrix, phylogenetic analysis
Research Article

Volume 7 Issue I - 2018

\author{
Vu Thi Trang,' Le Thi Quynh Chi, ${ }^{3}$ Chu Chi \\ Thiet, ${ }^{2}$ Nguyen Huu Duc, ${ }^{3}$ Tran Thi Thuy $\mathrm{Ha}^{\prime}$ \\ 'Centre of Aquaculture Biotechnology, Research Institute for \\ Aquaculture No. I, Vietnam \\ ${ }^{2}$ Aquaculture Research Sub-Institute for North Central \\ (ARSINC), Research Institute for Aquaculture No. I,Vietnam \\ ${ }^{3}$ Faculty of Biotechnology, Vietnam National University of \\ Agriculture,Vietnam
}

Correspondence: Vu Thi Trang, Centre of Aquaculture Biotechnology, Research Institute for Aquaculture No. I,Vietnam, Tel +84 972I 03043, Fax +84 243-827-3070,

Emailvttrang@rial.org

Received: January 19,2018| Published: February 27, 2018

\section{Introduction}

Asiatic hard clams (Meretrix meretrix), genus Meretrix (Veneridae), are commercially important species in coastal areas of South and Southeast Asia. ${ }^{1}$ In Vietnam, the northern coastal provinces is the main distributor for the total production of this species. ${ }^{2}$ These clams were considered to be one of the indigenous mollusks in this region. However, recently, in the coastal areas of some Northern provinces, White clams (Meretrix lyrata) or Ben Tre clams were entered from Southern provinces and produced artificially. As the consequences of rapid development, White clams dominate in number compared to indigenous clams with $85-90 \%$ of the mollusk yield. This has led to the changes in the structure of coastal organism communities in general and decrease rapidly the resource of M. meretrix in particular. ${ }^{3}$

There was a considerable number of studies about genetic of $M$ meretrix in Asia. Chen et al. ${ }^{4}$ present phylogenetic relationships of the genus Meretrix by using COI gene sequences. Thereafter, Chen et al. ${ }^{5}$ built phylogenetic tree for 106 individuals belonging to Veneridae family including M. meretrix. In 2011, He et al. ${ }^{6}$ used clam specimens collected from the coast of Panjin, Liaoning province, China for complete mitochondrial genome sequencing. The results showed that mitochondrial genome sequence of M. meretrix is $19,826 \mathrm{bp}$ in length, containing 37 genes, in which 12 protein-coding genes, 2 ribosomal RNAs, and 23 tRNAs. ${ }^{6}$ In general, the genetic studies of M. Meretrix in Asia focus primarily on analyzing the genetic relationship of them to closely related species. However, in Vietnam, studies have focused on resource assessment and reproductive biology, meanwhile, research on genetic of Asiatic hard clam has not paid much attention. The understanding of genetic structure and information about $M$. meretrix genetic diversity is necessary for the conservation, restoration, and development of this clam resource in Northern part of Vietnam.

Mitochondrial DNA (mtDNA) has been widely studied in almost marine and freshwater fish species, mainly for taxonomic and phylogenetic purposes. The advantages of using mtDNA include its simple maternal inheritance, absence of recombination, and high substitution rates. ${ }^{7}$ The mitochondrial COI gene is often used to distinguish species in animals because of faciliating in amplification by using PCR method and universal primers. ${ }^{8}$ This sequence of genes is always conserved among individuals in the same species and the rate of mutation is fast enough to distinguish between species with close genetic relationships. ${ }^{9}$ In this study, the mitochondrial COI gene sequence was used to identify species and genetic relationship analysis in Meretrix genus that were collected in some Northern coastal provinces in Vietnam. 


\section{Materials and methods}

\section{Samples collection}

In total, 60 samples were collected in six locations, including HaiPhong (HP), Thai Binh (TB), Nam Dinh (ND), ThanhHoa (TH), NgheAn (NA) and Ha Tinh (HT) with 10 samples per province (Table 1) (Figure 1). The name Asiatic hard clam is called according to the local community (with the Latin name is Meretrix meretrix). Based on morphological characteristics, collected samples were preliminarily identified as belonging to the $M$. meretrix. They are large clams with thick shell covered by thin, delicate, straw-coloured or grey periostracum, and a greyish-blue or bluish-brown band on its posterodorsal margin. The length is greater than the height. The muscle tissue $1-2 \mathrm{~g} / \mathrm{sample}$ was cut and preserved in $96 \%$ alcohol at $4{ }^{\circ} \mathrm{C}$.

Table I Collection details for Asiatic hard clam samples

\begin{tabular}{ccc}
\hline $\begin{array}{c}\text { Geographic populations } \\
\text { (abbreviation used) }\end{array}$ & $\begin{array}{c}\text { Sample location } \\
\text { (longitude and latitude) }\end{array}$ & $\begin{array}{c}\text { Collection } \\
\text { time }\end{array}$ \\
\hline HP & HaiPhong $\left(20^{\circ} 51^{\prime} 59^{\prime \prime} \mathrm{N}, 106^{\circ} 40^{\prime} 57^{\prime \prime} \mathrm{E}\right)$ & August, 2017 \\
TB & Thai Binh $\left(20^{\circ} 32^{\prime} 20^{\prime \prime} \mathrm{N}, 106^{\circ} 23^{\prime} 40^{\prime \prime} \mathrm{E}\right)$ & August, 2017 \\
ND & Nam Dinh $\left(20^{\circ} 25^{\prime} 13^{\prime \prime} \mathrm{N}, 106^{\circ} 10^{\prime} 05^{\prime \prime} \mathrm{E}\right)$ & September, 2017 \\
TH & ThanhHoa $\left(20^{\circ} 08^{\prime} 28^{\prime \prime} \mathrm{N}, 105^{\circ} 18^{\prime} 34^{\prime \prime} \mathrm{E}\right)$ & June, 2017 \\
NA & NgheAn $\left(19^{\circ} 10^{\prime} 35^{\prime \prime} \mathrm{N}, 104^{\circ} 58^{\prime} 38^{\prime \prime} \mathrm{E}\right)$ & May, 2017 \\
HT & Ha Tinh $\left(18^{\circ} 20^{\prime} 28^{\prime \prime} \mathrm{N}, 105^{\circ} 54^{\prime} 26^{\prime \prime} \mathrm{E}\right)$ & June, 2017 \\
\hline
\end{tabular}

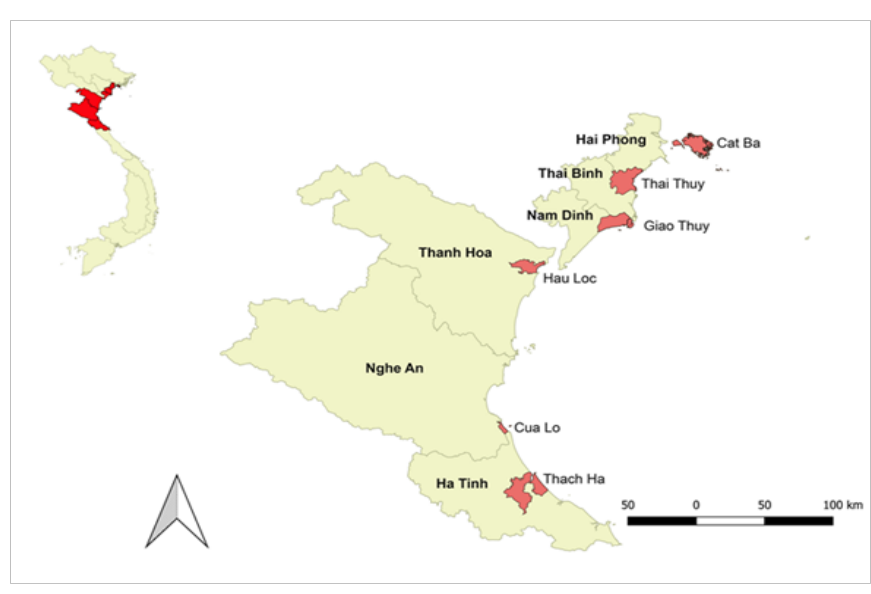

Figure I Map showing sample locations.

\section{DNA extraction, PCR amplification and sequencing}

Total DNA of 60 clam samples was extracted according to the alcohol precipitation method [10]. DNA quality was checked by $0.8 \%$ agarose gel electrophoresis and the absorbance at $260 \mathrm{~nm}$ was measured using Nanodrop and cuvette spectrophotometer (NanoDrop ${ }^{\mathrm{TM}}$ 2000C) to determine DNA concentration.

The fragments of COI gene of 60 samples were amplified by PCR reaction with primers according to Folmer et al. ${ }^{8}$ The primer sequence

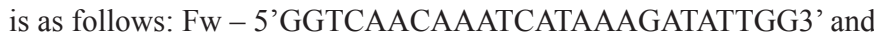
Rw - 5'TAAACTTCAGGGTGACCAAAAAATCA3'. PCR was carried out in a $37 \mu$ l volume containing $1 \mathrm{U} / \mu \mathrm{lTaq}$ DNA polymerase, $100 \mathrm{ng} / \mu \mathrm{l}$ template DNA, $10 \mu \mathrm{M}$ each primer $(1 \mu \mathrm{l}), 5 \mathrm{mM}(0.5 \mu \mathrm{l})$ of each dNTPs, $100 \mathrm{mM}$ TrisHCl (pH 8.3), $25 \mathrm{mM} \mathrm{MgCl}_{2}(2.5 \mu 1), 500 \mathrm{mM}$ $\mathrm{KCl}(\mathrm{pH} 8.3$ ). The PCR was employed with initial denaturation of 2 min at $94^{\circ} \mathrm{C}$ followed by 30 cycles of denaturation for $30 \mathrm{~s}$ at $94^{\circ} \mathrm{C}$, annealing at $45^{\circ} \mathrm{C}$ for $45 \mathrm{~s}$ and an extension of $72^{\circ} \mathrm{C}$ for $50 \mathrm{~s}$. After the completion of 30 cycles, a final extension step of $10 \mathrm{~min}$ at $72^{\circ} \mathrm{C}$ was performed. The PCR product was then kept at $4{ }^{\circ} \mathrm{C}$ until removed from the machine. The amplified product was tested in $1.5 \%$ agarose gel and visualized using the Uvitec system. The appropriate PCR products then were purified and sequenced.

\section{Data analysis}

Sequences of COIwaschecked by Finch TV 1.4.0sofware. ${ }^{11}$ Then, they were aligned and cut into the same length with BioEdit 7.2.5 using Clustal $\mathrm{W}$ under default settings. The BioEdit software was also used to check and determine the similarity degree of sequences and to create the consensus sequence of each population. The program DnaSP $5.0^{13}$ was used to analyze molecular diversity indices including haplotype diversity $(\mathrm{Hd})$, nucleotide diversity $(\pi)$. Hierarchical analyses of molecular variance (AMOVA) were performed using Arlequin $3.5^{14}$ to evaluate population structure. Haplotype network was constructed by using Network 4.6.1. ${ }^{15}$

Analysis of genetic distance between populations was used MEGA 6.0. ${ }^{16}$ The evolutionary history was inferred using the NeighborJoining method. ${ }^{17}$ The evolutionary distances were computed using the Kimura 2-parameter method ${ }^{18}$ and are in the units of the number of base substitutions per site. Venerupis/Ruditapes philippinarum (EU266378.1) and Meretrix petachialis (KY318134.1) were used as out group.

\section{Results and Discussion}

\section{M. meretrix identification based on $\mathrm{COI}$ region}

The Blast results from National Center for Biotechnology Information (NCBI) showed that in total of 59 samples, there are 19 samples (32.2\%) of M. meretrix with $99-100 \%$ identity (Table 2). 
These results illustrated that species identification by morphology and molecular biology produced different results. By morphology method, $100 \%$ of the samples were classified as M. meretrix. However, by molecular biology method, only $32.2 \%$ of samples were identified as $M$. meretrix based on COI sequences. The remaining $(67.8 \%)$ were identified as M. petechialis. According to Prashad, ${ }^{19}$ M. meretrix is a species which experienced the greatest variation in the group of bivalves. Because of shades of shells and shell colors, it was wrongly identified with other species. ${ }^{19}$ The results obtained in this study do not support the present taxonomic status of $M$. meretrix and $M$. petechialis, our goal is to analyze the genetic relationship of M.meretrix in different geographic regions of Vietnam. Specially, we focused to analyze genetic relationship of $3 \mathrm{M}$. meretrix populations in Thai Binh, Nam Dinh, Nghe An provinces.

Table 2 Number of samples belonging M. meretrix species in investigated populations

\begin{tabular}{ccccc}
\hline Population & $\begin{array}{c}\text { No. of } \\
\text { samples }\end{array}$ & $\begin{array}{c}\text { No. of analyzed } \\
\text { sequences }\end{array}$ & $\begin{array}{c}\text { No. of } \text { M.meretrix } \\
\text { species }\end{array}$ & Rate (\%) \\
\hline Hai Phong & 10 & 10 & 0 & 0 \\
Thai Binh & 10 & 10 & 6 & 60 \\
Nam Dinh & 10 & 10 & 3 & 30 \\
Thanh Hoa & 10 & 10 & 0 & 0 \\
Nghe An & 10 & 10 & 8 & 80 \\
Ha Tinh & 10 & 9 & 2 & 22
\end{tabular}

\section{Genetic relationship between $M$. meretrix populations}

\section{Mitochondrial genetic diversity}

The fragments of COI sequences $(650 \mathrm{bp})$ were obtained from 17 clams from the 3 of 6 populations studied (Thai Binh, Nam Dinh,
NgheAn) which had more than 2 clams identified as M. meretrix (with GenBank accession numbers is DQ399399.1). In which, 6 polymorphic sites, 3 parsimony informative sites and 4 haplotypes were observed for the COI gene. The results of $M$. meretrix populations genetic diversity were shown in Figure 2 \& Table 3.

Table 3 Mitochondrial genetic diversity of studied M. Meretrix populations

\begin{tabular}{ccccc}
\hline Sample site & $\begin{array}{c}\text { No. of } \\
\text { sequences }\end{array}$ & $\begin{array}{c}\text { No. of } \\
\text { haplotype }(\mathrm{h})\end{array}$ & $\begin{array}{c}\text { Haplotype } \\
\text { diversity } \\
(\mathrm{Hd} \pm \mathrm{SD})\end{array}$ & $\begin{array}{c}\text { Nucleotide } \\
\text { diversity }(\Pi \pm \mathrm{SD})\end{array}$ \\
\hline Thai Binh & 6 & 2 & $0.333 \pm 0.215$ & $0.00051 \pm 0.00033$ \\
Nam Dinh & 3 & 2 & $0.667 \pm 0.314$ & $0.00204 \pm 0.00096$ \\
Nghe An & 8 & 2 & $0.429 \pm 0.619$ & $0.00197 \pm 0.00078$ \\
Total & 17 & 4 & $0.476 \pm 0.233$ & $0.00151 \pm 0.00069$ \\
\hline
\end{tabular}

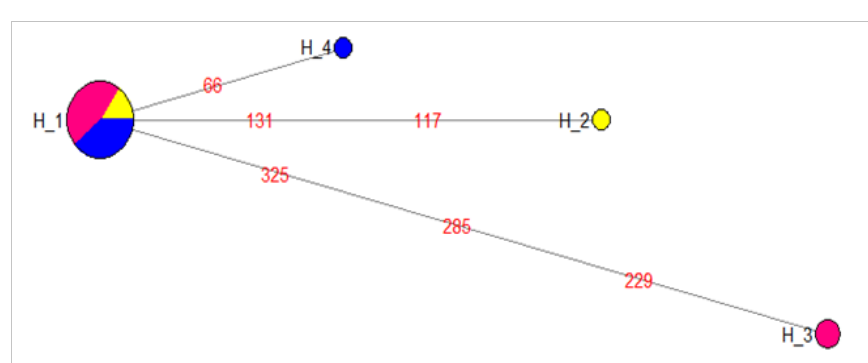

Thai Binh

Nam Dinh

Nghe An

The COI network was radial-like with a number of unique haplotypes closely related to central haplotype. Figure 2 indicated that the haplotype H_1, accounted for $76.47 \%$ (13/17), of all 17 individuals; occupied the central position of the network, one step away with other 3 haplotypes. This also suggested that $\mathrm{H}_{-} 1$ was the ancestral haplotype and $M$. meretrix populations had an intimate genetic relationship. Besides, each population had its own haplotype which specific to the population. Hence, there was no population structure or population structure is not clearly established among studied populations the overall haplotype diversity and nucleotide diversitywere $0.476 \pm 0.233$ and $0.00151 \pm 0.00069$, respectively. The Hd ranged from $0.333 \pm 0.215$ (Thai Binh population) to $0.667 \pm 0.314$ (Nam Dinh population). Nucleotide diversity was highest $(0.00204 \pm 0.00096)$ in Nam Dinh population and lowest $(0.00051 \pm 0.00033)$ in Thai Binh population. Hd and $\pi$ values in this study were lower than previous study on Meretrix petechialis and Ruditapes philippinarum using the same method. In fact, these values were $0.9483 \pm 0.0054$ and $0.03364 \pm 0.01638$, respectively

Figure 2 Network of studied M. meretrix populations. 
in Meretrix petechialis collected in the Northwestern Pacific. ${ }^{20}$ In Manila clam (Ruditapes philippinarum), Hd values were ranged from 0.80 to 1.00 while $\pi$ values fluctuated $0.17-1.08$ in populations collected in Asia. ${ }^{21}$ Grant and Bowen, 1998 pointed out that marine species which experienced rapid expansion following a period of low effective population size often display high haplotype but medium to low nucleotide diversities. ${ }^{22}$ Genetic diversity can be influenced by a range of factors including sample size, natural selection, mutation rates, gene flow among populations and human factors. ${ }^{23}$ Previous studies revealed high genetic diversity in marine species including the miiuy croaker (Miichthys miiuy), ${ }^{24}$ the fat greenling (Hexagrammos otakii), ${ }^{25}$ and the clam (Macridiscus multifarius). ${ }^{26}$
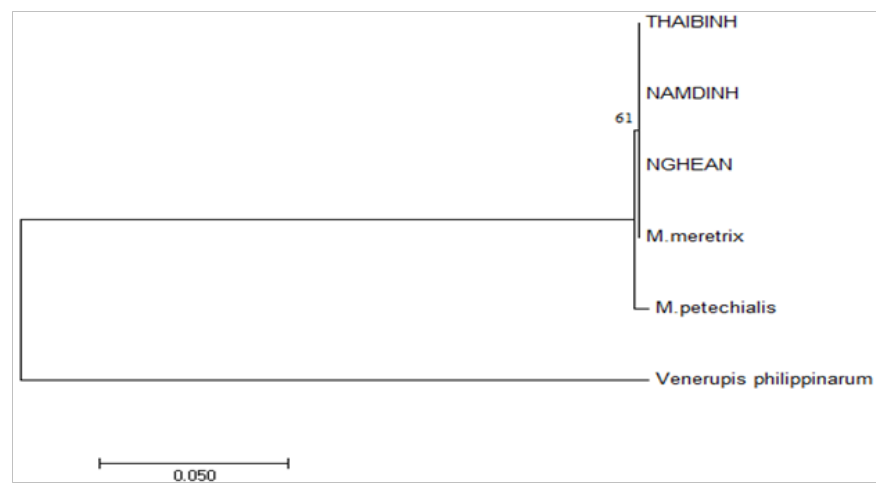

Figure 3 Dendrogram (NJ tree) based on Nei (1978) genetic distance between $3 \mathrm{M}$. meretrix populations. ${ }^{28}$

\section{Genetic differentiation and genetic distance}

$\mathrm{F}_{\mathrm{ST}}$ values (Table 4) indicated the levels of pair wise genetic differentiation between the 3 populations. The $\mathrm{F}_{\mathrm{ST}}$ values between populations were moderate $\left(\mathrm{F}_{\mathrm{ST}}<0.15\right)$, in which the lowest $\mathrm{F}_{\mathrm{ST}}$ value was observed between the Nam Dinh and NgheAn populations $\left(\mathrm{F}_{\mathrm{ST}}=\right.$ 0.07996), while the highest $F_{S T}$ value was observed between the Nam Dinh and Thai Binh populations $\left(\mathrm{F}_{\mathrm{ST}}=0.13333\right)$.

Table 4 Genetic differentiation (above) and genetic distance (below) of $3 \mathrm{M}$. meretrix populations

\begin{tabular}{cccc}
\hline & Nam Dinh & Thai Binh & Nghe An \\
\hline Nam Dinh & $\square$ & $0.13333^{*}$ & $0.07996^{*}$ \\
Thai Binh & 0.001 & $\square$ & $0.08789 *$ \\
Nghe An & 0.002 & 0.001 & $\square$
\end{tabular}

$(*:$ v value $<0.05)$

The genetic differentiation $\left(\mathrm{F}_{\mathrm{ST}}\right)$ increased as geographic distance increased was correct for the case of the relationship between Nghe An population and the other, but it was not correct for other relationships. Genetic differentiation is influenced by many factors including habitat differences, historical events and human activities. ${ }^{27}$

The genetic distance values ranged from 0.001 (Thai Binh NgheAn, Thai Binh - Nam Dinh) to 0.002 (Nam Dinh - Nghe An). The variation in genetic distance was not correlated with geographic distance. In this study, the geographic distance between NgheAn Thai Binh was highest, but the genetic differentiation between Nam Dinh - NgheAn were largest.

Hierarchical analysis of AMOVA (Table 5) showed that majority of the molecular variation was distributed within populations (91\%) rather than among populations $(9 \%)$, indicating that the total genetic variation was intrapopulation variation. Therefore, it can be found that the population structure was not clearly established and the genetic diversity was low among studied populations. The $\mathrm{F}_{\mathrm{ST}}$ value was 0.08999 which means there were moderate significant genetic variations among the three $M$. meretrix populations. Therefore, the use of only COI marker for the mtDNA region had not been polymorphic in this study.

\section{Phylogenic analysis}

Phylogenetic relationships were showed among $M$. meretrix species and outgroup Meretrix petechialis and Venerupis philippinarum. Because of the limitation in number of M. meretrix samples (3-8 samples per population) and the mixing population among three provines, there was no or less significant differences between populations consensus sequences. Tree topologies indicated that three $M$. meretrix populations and M. meretrix COI gene sequence (Accession number: DQ399399.1) formed a monophyletic group with very small or no genetic variation among populations.

M. meretrix and M. petechialis have been known as closely related species and there were some suggestions that they should be considered as synonyms ${ }^{4,6}$. However, as of now, the classification of $M$. meretrix and $M$. petechialis are still debated and unanimously agreed on the morphological and molecular biology identification methods. According to previous studies, $M$. meretrix was only distributed in the South China Sea, while M. petechialis was widely distributed throughout the coasts of $\mathrm{China}^{29}$ and they were often misidentified. ${ }^{20}$ In another similar case, Chen et al., ${ }^{4}$ supposed that M. petechialis and $M$. lusoria should be treated as a junior synonym of $M$. meretrix but as the reported by Torii et al., ${ }^{30} \mathrm{M}$. petechialis and M. lusoria are the two different species. Moreover, these authors established a method to identify M. lusoria and M. petechialis from shell morphology which can identify with $98.89 \%$ correct percentage.

Table 5 Results from analysis of molecular variance (AMOVA) of populations

\begin{tabular}{cccccc}
\hline Source of variation & d.f. & Sum of squares & $\begin{array}{c}\text { Variance } \\
\text { components }\end{array}$ & $\begin{array}{c}\text { Percentage of } \\
\text { variation }\end{array}$ & $\begin{array}{c}\text { Fixation } \\
\text { Index } \mathbf{F}_{\text {ST }}\end{array}$ \\
\hline Among populations & 2 & 1.451 & 0.04709 & 9 & 0.08999 \\
Within populations & 14 & 6.667 & 0.47619 & 91 \\
Total & 16 & 8.118 & 0.52328 & & \\
\hline
\end{tabular}




\section{Conclusions}

Nineteen out of 59 samples were identified as M. meretrix. The M. meretrix populations had moderate genetic diversity that revealed by values of haplotype diversity and nucleotide diversity. The genetic differentiation $\left(\mathrm{F}_{\mathrm{ST}}\right)$ was relatively high, however, the genetic distance (DA) was low and not related with geographic distance. Total genetic variation was intrapopulation variations. There was no clear population structure established among studied populations. The obtained results of this study have contributed scientific basis about genetic data of Asiatic hard clam in some regions in Vietnam. This is the basis for scientists, managers and people to build timely measures to research, preserve and develop clam genetic resources in the future.

\section{Acknowledgments}

The study was supported by Research Institute for Aquaculture No.1, Vietnam

\section{Conflict of interest}

None.

\section{References}

1. Tang B, Liu B, Wang G, et al. Effects of various algal diets and starvation on larval growth and survival of Meretrix meretrix. Aquaculture. 2006;254(1):526-533

2. Phung NH, Tuan VS, Yet NH. Distribution and economic resources of Gastropoda class and Bivalvia class in Vietnam coastal areas. Proceeding of the first national workshop on marine mollucs, Agricultural Publisher, Ho Chi Minh. 2001:27-60.

3. Thanh NX, Thuoc P, Khoi TC (2013) Situation and development orientation of clam culture in Nam Dinh. Journal of Marine Science and Technology. 2013;13(1):88-94.

4. Chen A-h, Li Z-x, Feng G-n. Phylogenetic relationships of the Genus Meretrix (Mollusca: Veneridae) Based on Mitochondrial COI Gene Sequences. Zoological Research. 2009;30(3):233-239.

5. Chen J, Qi Li, Lingfeng Kong, et al. Molecular phylogeny of venus clams (Mollusca, Bivalvia, Veneridae) with emphasis on the systematic position of taxa along the coast of mainland China. Zoologica Scripta. 2011;40(3):260-271.

6. He CB, Wang J, Gao XG, et al. The complete mitochondrial genome of the hard clam Meretrix meretrix. Mol Biol Rep. 2011;38(5):3401-9.

7. Wolstenholme DR. Animal mitochondrial DNA: structure and evolution Int Rev Cytol. 1992;141:173-216.

8. Folmer O, Black M, Hoeh W, et al. DNA primers for amplification of mitochondrial cytochrome c oxidase subunit I from diverse metazoan invertebrates. Mol Mar Biol Biotechnol. 1994;3(5):294-9.

9. Rebijith KB, Asokan R, Kumar NKK. Molecular identification of Mealybugs. In: Mani M, Shivaraju C, editors. Mealybugs and their Management in Agricultural and Horticultural crops. New Delhi: Springer. 2016:75-86.

10. Sambrock J, W Russel D. Molecular Cloning: A Laboratory Manual. $3^{\text {rd }}$ ed. Cold pring Harbor Laboratory Press, New York; 2001.

11. http://www.geospiza.com

12. Thompson JD, Higgins DG, Gibson TJ. CLUSTAL W: improving the sensitivity of progressive multiple sequence alignment through sequence weighting, position-specific gap penalties and weight matrix choice. Nucleic Acids Res. 1994;22(22):4673-80.

13. Rozas J, Sanchez-DelBarrio JC, Messeguer X. DNA polymorphism analyses by the coalescent and other methods. Bioinformatics. 2003;19(18):2496-7.

14. Excoffier L, Smouse PE, Quattro JM. Analysis of molecular variance inferred from metric distances among DNA haplotypes: application to human mitochondrial DNA restriction data. Genetics. 1992;131(2):479_ 91.

15. Bandelt HJ, Forster P, Rohl A. Median-joining networks for inferring intraspecific phylogenies. Mol Biol Evol. 1999;16(1):37-48.

16. Tamura K, Stecher G, Peterson D, et al. MEGA6: Molecular Evolutionary Genetics Analysis version 6.0. Mol Biol Evol. 2013;30(12):2725-9.

17. Saitou N, Nei M. The neighbor-joining method: a new method for reconstructing phylogenetic trees. Mol Biol Evol. 1987; 4(4):406-25.

18. Kimura M. A simple method for estimating evolutionary rates of base substitutions through comparative studies of nucleotide sequences. $J$ Mol Evol. 1980;16(2):111-20.

19. Prashad B. The Lamellibranchia of the Siboga expedition. Systematic part. II. Pelecypoda (exclusive of the Pectinidae). Siboga-Expenditie, Leiden. 1932;212-264.

20. Wang X, Kong L, Chen J, et al. Phylogeography of bivalve Meretrix petechialis in the Northwestern Pacific indicated by mitochondrial and nuclear DNA data. PLoS One. 2017;12(8):e0183221.

21. Cordero D, Delgado M, Liu B, et al. Population genetics of the Manila clam (Ruditapes philippinarum) introduced in North America and Europe. Scientific Reports. 2017;7:39745.

22. Grant WAS, Bowen BW. Shallow population histories in deep evolutionary lineages of marine fishes: insights from sardines and anchovies and lessons for conservation. Journal of Heredity. 1998;89(5):415-26.

23. Frankham R. Challenges and opportunities of genetic approaches to biological conservation. Biological Conservation. 2010;143(9):191927.

24. Xu T, Zhu Z, Sun Y, et al. Characterization and expression of the CXCR 1 and CXCR4 in miiuy croaker and evolutionary analysis shows the strong positive selection pressures imposed in mammal CXCR1. Dev Comp Immunol. 2014;44(1):133-44.

25. Habib KA, Jeong D, Myoung J-G, et.al. Population genetic structure and demographic history of the fat greenling Hexagrammos otakii. Genes \& Genomics. 2011;33(4):413-23.

26. Ye YY, Chang WW, Ji JL. Genetic Population Structure of Macridiscus multifarius (Mollusca: Bivalvia) on the Basis of Mitochondrial Markers: Strong Population Structure in a Species with a Short Planktonic Larval Stage. PLOS ONE. 2015;10(12):e0146260.

27. Grant JA, Wilson SA, Ruff SW, et al. Distribution of rocks on the Gusev Plains and on Husband Hill, Mars. Geophysical research letters. 2006;33(16).

28. Nei M. Estimation of average heterozygosity and genetic distance from a small number of individuals. Genetics. 1978; 89(3):583-90.

29. Zhang S, Wang H, Xu F. Taxonomic study on Meretrix (Bivalvia, veneridae) from China Seas. Acta Zoo-taxonomica Sinica. 2012;37:473479 .

30. Torii H, Sato Si, Hamaguchi M, et al. The comparison of shell morphology and genetic relationship between Meretrix lusoria and M. petechialis in Japan and Korea. Plankton Benthos Res. 2010;5 Suppl:231-241. 